\title{
PENINGKATAN KETERAMPILAN MENYIMAK KOMPREHENSIF DAN KRITIS DENGAN METODE RESITASI PADA MAHASISWA
}

\author{
Wiendi Wiranty \\ Program Studi Pendidikan Bahasa dan Sastra Indonesia, Fakultas Bahasa dan Seni IKIP PGRI \\ Pontianak, Jalan Ampera Nomor 88 Pontianak 78116 \\ e-mail: wiendiwiranty88@gmail.com
}

\begin{abstract}
Abstrak
Tujuan penelitian untuk mengetahui bagaimana proses dan hasil peningkatan keterampilan menyimak komprehensif dan kritis dengan metode resitasi pada mahasiswa. Masalah penelitian adalah bagaimana proses dan hasil meningkatkan keterampilan menyimak komprehensif dan kritis menggunakan metode resitasi? Metode penelitian adalah penelitian tindakan kelas (PTK). Teknik pengumpul data menggunakan teknik komunikasi langsung, obseryasi, pehgukuran, dan dokumentasi. Alat pengumpul data menggunakan angket, panduann pbservasi, pedoman wawancara, tes, dan dokumentasi. Teknik anglisis data meggunakan teknik statistik deskriptif komparatif dan analisis kritis Hasil penelitian menunjukkan terjadi peningkatan yang signifikan antara siktus $\mathbf{I}$ dan siklus II. Siklus I terjadi peningkatan menjadi $60,01 \%$ dan siklus mencapai $78,50 \%$. Sehingga dapat disimpulkan penerapan metode resitasi pada mata kuliah menymak komprehensif dan kritis dinyatakan dapat meningkatkan keterampilan menyimak mahasiswa.
\end{abstract}

Kata Kunci: menyimak komprehensif dan kritis, resitasi, PTK.

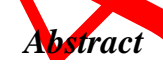

This research aimed at improving students' listening comprehension and critical ability through recitation method. The research problem is how to improve students' listening comprehension and critical ability through recitation method? The research method is classroom action research $(C A R)$. Data were collected by direct communication, observation, measurement, and documentation technique. Data collection tools used questionnaires, observation guides, interview guidelines, tests, and documentation. Data analysis techniques used comparative descriptive statistical techniques and critical analysis. The results showed a significant increase between I and II cycles. The I cycle increased to $60.01 \%$ and the II cycle reached $78.50 \%$. This study concludes that applying recitation methodcan improve students' listening skills.

Keywords: comprehension and critical listening, recitation, CAR.

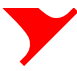

\section{PENDAHULUAN}

Mahasiswa tidak bisa lepas dari interaksi dan komunikasi, baik dengan sesama mahasiswa, dosen, keluarga, dan masyarakat. Proses interaksi dan komunikasi diperlukan keterampilan berbahasa aktif, kreatif, produktif, dan resesif apresiatif yang salah satu unsurnya adalah keterampilan menyimak yang bertujuan untuk menangkap dan memahami pesan ide serta gagasan yang terdapat 
pada materi atau bahasa simakan. Karena sering kali dalam berinteraksi dan berkomunikasi mengalami kendala "kita (sebagai simakan) atau orang lain (sebagai penyimak) tidak dapat menangkap dengan baik pesan ide atau gagasan pada saat komunikasi berlangsung."

Manusia merupakan makhluk individual sekaligus makhluk sosial. Manusia harus bergaul dan berhubungan dengan manusia lain. Sebagai makhluk sosial, manusia sering memerlukan orang lain untuk memahami apa yang sedang dipikirkan, apa yang dirasakan, dan apa yang diinginkan. Pemahaman terhadap pikiran, kehendak, dan perasaan orang lain dapat dilakukan dengan menyimak. Dalam kaitan dengan kemampuan menyimak, mahasiswa harus mampu mengingat fakta-fakta sederhana, mampu menghubungkan serangkaian fakta dari pesan yang didengarnya, dan menafsirkan makna yang terkandung dalam pesan lisan yang didengarnya.

Tarigan (1997), menyatakan bahwa menyimak bukan hanya sebatas mendengar (hearing) saja, tetapi memerlukan kegiatan lainnya yakni memahami (understanding) isi pembicaraan yang disampaikan oleh si pembicara. Lebih jauh lagi diharapkan dalam menafsirkan (interprenting) butir-butir pendapat yang disimaknya baik tersurat maupun tersirat. Kegiatan selanjutnya dalam proses menyimak adalah kegiatan mengevaluasi (evaluating). Si penyimak menilai gagasan baik dari segi keunggulan maupun dari segi kelemahannya. Kegiatan akhir yakni menanggapi (responding). Penyimak menyebut, mencamkan, menyerap, serta menerima gagasan yang dikemukakan oleh si pembicara.

Menyimak merupakan salah satu keterampilan berbahasa yang penting dalam kehidupan sehari-hari, baik secara langsung maupun melalui media elektronik. Dalam pengertian sempit berarti seseorang melakukan kegiatan menyimak yang mengacu pada proses mental. Pendengar menerima rangsangan bunyi dari pembicara, kemudian menyusun penafsirannya. Dalam pengertian yang lebih luas, menyimak tidak hanya mengerti dan membuat penafsiran tertentu akan tetapi berusaha untuk melakukan apa yang disimaknya.

Menyimak dengan tujuan pemahaman dan pemaknaan secara keseluruhan tergolong kepada menyimak komprehensif. Pada penelitian yang dilakukan, 
menyimak yang digunakan adalah menyimak komprehensif dan kritis. Mendengar untuk tujuan memahami disebut juga menyimak komprehensif. Seseorang dapat dikatakan sebagai penyimak komprehensif yang baik apabila mampu menerima, memperhatikan, dan memberikan makna dari pesan yang sedekat mungkin sama dengan pesan yang disampaikan oleh pembicara. Menyimak kritis adalah sejenis kegiatan menyimakyang berupa untuk mencari kesalahan atau kekeliruan bahkan juga untuk mencari kebaikan dan kebenaran dari ujaran seseorang (Tarigan, 1994).

Suatu proses belajar mengajar tidak hanya sekedar proses nemberi pelajaran atau menerima pelajaran. Namun, terdapat proses penerimaan ilonu dari dosen kepada mahasiswa. Untuk dapat terjadi proses transfer ilmu tersebut perlu metode-metode untuk mencapai tujuan dari permbelajaran. Sehingga metode atau model pembelajaran dapat menjadikan proses belajar mengajar semakin efektif dan efisien. Menurut Sudjana (2005), metode pempelajaran adalah cara yang dipergunakan guru dalam mengadakan hubungan dengan siswa pada saat berlangsungnya pengajaran. Pada penelitian yang dilakukan, peneliti menggunakan metode resitasi untuk meningkatkan keterampilan menyimak komprehensif dan kritis.

Metode resiasi merupakan metode pemberian tugas kepada siswa di luar jadwal sekolah atau di luar jadwal pelajaran yang pada akhirnya dipertanggungjayabkan kepada dosen yang mengampu mata kuliah menyimak. Metode resitasi satu diantara pilihan metode mengajar seorang dosen. Dosen memberikan sejumlah item tes kepada mahasiswa untuk dikerjakan di luar jadwal mata kuliah. Pemberian item tes biasanya dilakukan pada setiap kegiatan belajar di kelas, pada akhir setiap pertemuan atau akhir pertemuan di kelas. Pemberian tugas merupakan satu diantara alternatif untuk lebih menyempurnakan penyampaian tujuan pembelajaran khusus. Hal tersebut disebabkan oleh padatnya materi pelajaran yang harus disampaikan sementara waktu belajar sangat terbatas di dalam kelas.

Menurut Purwanto (2002), metode resitasi berarti mengulangi atau mengucapkan kembali (sesuatu) yang dipelajari. Slameto (2010), menyatakan 
bahwa metode resitasi adalah cara penyampaian bahan pelajaran dengan memberikan tugas kepada siswa untuk dikerjakan di luar jadwal sekolah dalam rentang waktu tertentu dan hasilnya harus dipertanggungjawabkan kepada guru. Sedangkan menurut Muniarsih dan Fayeldi (2017), metode resitasi diterapkan sebagai upaya untuk mendukung dan mempermudah kegiatan belajar mengajar di kelas.

Sudirman (1992), mengemukakan langkah-langkah yang ditempuh dalam pelaksanaan pembelajaran dengan metode resitasi yaitu: (1) Tugas yang diberikan harus jelas; (2) Tempat dan lama waktu penyelesaian tugas harus jelas; (3) Tugas yang diberikan terlebih dahulu dijelaskan/diberikan perunjuk yang jelas, agar mahasiswa yang belum mampu memahami tugas tersebut bełupaya untuk menyelesaikannya; (4) Dosen harus memberikan bimbingan tramanya kepada mahasiswa yang mengalami kesulitan belajar atau salah arah dalam mengerjakan tugas; dan (5) Memberi dorongan terutana bagi mahasiswa yang terlambat atau kurang bergairah mengerjakan tugas

Kemampuan mahasiswa dalam menyimak komprehensif dan kritis masih rendah. Hal tersebut diturjukkan dengan belum tuntas atau tercapainya KKM yang ditentukan oleh dosen pengampu nata kuliah yaitu 75. Penyebabnya adalah kurangnya motivasi dan semangat mahasiswa selama proses pembelajaran. Kekurangberhasilan pembelajaran menyimak disebabkan oleh sistem pembelajaran yang masih terpusat pada dosen. Mahasiswa kurang diberi kesempatan untuk berlatih dan mengembangkan kreativitasnya. Mahasiswa terpola dalam pembelajaran yang pasif. Untuk mengatasi permasalahan, maka diperlukan formula yang dapat membangkitkan daya ingat mahasiswa terhadap apa yang didengar atau diterima dari bahan pelajaran yang diberikan oleh dosen dengan pemberian metode belajar yang tepat dan efektif, yaitu dengan metode resitasi.

\section{METODE}

Metode penelitian menggunakan penelitian tindakan kelas. Data penelitian yang dikumpulkan adalah tentang proses dan hasil pembelajaran mata kuliah 
menyimak komprehensif dan kritis dengan sumber data adalah mahasiswa. Penelitian dilakukan pada mahasiswa kelas A Sore semester 2 angkatan 2017. Lokasi penelitian di IKIP PGRI Pontianak.

Teknik pengumpulan data yaitu studi dokumenter, observasi, wawancara, dan pengukuran. Alat pengumpul data yaitu lembar observasi, pedoman wawancara, dan tes. Tes digunakan untuk mengetahui bagaimana proses serta hasil pembelajaran menyimak komprehensif dan kritis dengan menggunakan metode resitasi pada mahasiswa. Teknik analisis data yang drgunakan adalah teknik deskripstif komparatif dan analisis kritis. Teknik deskriptif komparatif digunakan untuk membandingkan hasil antarsiklus sedangkan teknik analisis kritis digunakan untuk mengungkapkan kelemahan dan kelebihan kinerja siswa dan guru dalam proses belajar mengajar berdasarkan kriteria normatif yang diturunkan dari hasil teoretis maupun dari ketentuan yang ada secara kritis. Prosedur penelitian mencakup langkah-langkah: persiapan, studi/survei awal, pelaksanaan siklus, dan penyusunan laporan. Banyaknya siklus yang dilakukan adalah 2 siklus.

\section{HASIL D
Prasiklus}

Metode yang digunakan oleh dosen dalam proses pembelajaran prasiklus yang berlangsung di kelas adalah metode ceramah dan terkadang dicampur dengan metode yang lain seperti praktik dan pemberian tugas. Dosen juga jarang menggunakan media pembelajaran sehingga proses pembelajaran menjadi monoton dan berfokus pada dosen. Mahasiswa hanya merespon pertanyaan dosen apabila ditunjuk. Pada proses pembelajaran peran dosen masih mendominasi sehingga mahasiswa kurang mendapat kesempatan untuk lebih banyak terjun langsung dalam sebuah proses pembelajaran menyimak komprehensif dan kritis.

Berdasarkan temuan di lapangan, pelaksanaan pembelajaran sebelum menggunakan metode resitasi belum bisa dikatakan baik. Proses pembelajaran menyimak komprehensif dan kritis masih terpusat pada dosen sehingga proses pembelajaran terasa sangat monoton. Pemberian tugas juga dirasakan belum 
maksimal karena kurangnya pengawasan terhadap hasil kinerja mahasiswa. Hasil praobservasi menunjukkan $40 \%$ mahasiswa yang tuntas atau mencapai nilai KKM yang ditentukan oleh dosen pengampu dengan jumlah ketuntasan klasikal 35\% (10 orang) dari 100\% (40 orang) mahasiswa. Hal tersebut menunjukkan perlu dilakukan perbaikan dengan penggunaan metode yang sesuai dengan tujuan dari keterampilan menyimak komprehensif dan kritis. Jika mahasiswa berhasil mencapai KKM 75 dari 75\% mahasiswa, maka tingkat ketuntasan belajar tercapai dan siklus akan dihentikan serta penelitian dinyatakan selesai.

\section{Siklus I}

Hasil penelitian tindakan kelas yang dilakukan pada siklus I pertemuan pertama dan kedua masih ditemukan hasil yang kurang menuaskan, hal tersebut terlihat dari hasil lembar observasi siswa dan garu. Mahasiswa kurang berminat dalam menyimak koprehensif dan kritis te hadap apa yang disampaikan dosen di kelas sehingga mengakibatkan kurang terlaksananya proses pembelajaran di kelas dengan baik dan diperlukan upaya dosen dalam meningkatkan keterampilan menyimak sehingga proses pelaksanaan yang disajikan dapat mencapai tujuan pembelajaran yang diharapkan. Berdasarkan hasil pengamatan siklus I dosen mulai terbiasa menggthakan metode resitasi. Hal tersebut tampak pada hasil dalam kinerja mahasiswa yang mencapai 60,01\%. Peningkatan juga terlihat pada proses pembelajâran yaitu dosen memberikan bimbingan kepada mahasiswa dalam belajar dan diskusi kelompok, dosen memberikan arahan dalam mengerjakan tugas, menbimbing mahasiswa dalam menyimpulkan selama proses pemberian tugas serta memberikan langkah-langkah dalam pelaksanaan tugas kepada mahasiswa.

Pada tahap refleksi dilakukan setelah pelaksanaan siklus I. berdasarkan data yang diperoleh selama observasi siklus I, maka peneliti menemukan beberapa kelemahan sebagai berikut: (1) Sebagian mahasiswa masih mengalami kesulitan dalam proses pembelajaran menyimak komprehensif dan kritis dengan menggunakan metode resitasi, terlihat dari hasil observasi 60,01\%; (2) Mahasiswa kurang termotivasi belajar, kurang berminat dalam belajar, serta belum terbiasa selama pelaksanaan proses belajar dengan metode resitasi; dan (3) Dosen belum 
maksimal dalam penggunaan metode resitasi, terlihat dari kurang nya pengawasan dari dosen pengampu mata kuliah sehingga masih ada mahasiswa yang melakukan penipuan dimana mahasiswa hanya meniru hasil pekerjaan orang lain tanpa mau bersusah payah mengerjakan sendiri. Terkadang tugas dikerjakan oleh orang lain tanpa pengawasan, dan sukar memberikan tugas yang memenuhi perbedaan individu, serta dosen sering memberikan tugas yang monoton (tidak bervariasi).

Berdasarkan kelemahan yang diperoleh pada siklus I, peneliti menawarkan cara mengatasi kelemahan berupa tugas yang diberikan kepada mahasiswa hendaknya jelas, sehingga mahasiswa dapat mengetahui dengan jelas apa yang harus dikerjakan. Dan pada siklus ke II dosen akan memberikan tugas yang berbeda dari tugas pada siklus I tapi dengan tujuan yang sama untuk meningkatkan kemapuan menyimak mahasiswa. Tujuan pemberian tugas yang berbeda adalah untuk melihat tingkat pemahaman dan proses dari hasil penerapan metode resitasi siklus I.

Tugas yang diberikan kepada mahasiswa dengan memperlihatkan perbedaan individu masing-masing. Waktu untuk menyelessaikan tugas masih sama antara siklus I dan siklus II. Dosen akan tetap mengawasi mahasiswa pada saat mengerjakan tugas serta memberikan semangat dan motivasi kepada mahasiswa untuk belajar dengan sungguh-sungguh.Tugas yang diberikan hendaknya mempertimbangkan minat mahasiswa, bersifat praktis dan ilmiah. Terakhir dosen meberikan pengakuan atau penghargaan terhadap hasil kerja mahasiswa sehingga mahasiswa lebih termotrvasi selama proses pembelajaran.

Keterampilan menyimak komprehensif dan kritis pada mahasiswa setelah diterapkan metode resitasi dapat dijelaskan sebagai berikut: (1) Tujuan menyimak komprehensif dan kritis yang diamati secara seksama meningkat menjadi 60,01\%, terjadi peningkatan yang signifikan dari praobservasi; (2) Tahap-tahap menyimak yang diamati secara seksama meningkat menjadi 55,02; (3) Penerimaan, perhatian, dan pemberian makna dari pesan yang disampaikan meningkat menjadi 62,05\%; dan (4) Proses penafsiran dalam mencari kesalahan atau kekeliruan bahkan mencari kebenaran atau kebaikan dari ujaran seseorang meningkat menjadi $63 \%$. 
Peningkatan terjadi dikarenakan penggunaan metode resitasi oleh dosen telah dilakukan dengan baik walaupun hasil yang diperoleh belum maksimal, sehingga diperlukan langkah yang komprehensif oleh dosen dalam meningkatkan keterampilan menyimak komprehensif dan kritis pada mahasiswa. Berdasarkan beberapa pertimbangan, maka penelitian akan dilanjutkan pada siklus II.

\section{Siklus II}

Pelaksanaan siklus II dengan metode resitasi sudah dilaksanakan dengan baik dan maksimal serta hasil belajar yang diperoleh mencapai ketentuan target KKM 75 dengan ketuntasan klasikal 78,50\%. Hal térsebut menunjukan peningkatan yang sangat signifikan sehingga penelitian dinyatakan selesai. Tujuan menyimak komprehensif dan kritis tercapai dengan indikator pehahaman dan pemaknaan secara keseluruhan, mendengar untuk tujuan mernahami, mampu menerima, memperhatikan, dan memberikan makna dari pesan yang sedekat mungkin sama dengan pesan yang disampakan oleh pembicara.

Dosen melaksanakn proses pembelajaran sudah sesuai dengan rencana pelaksanaan pembelajaran dan menyelesaikan proses pembelajaran sesuai dengan waktu yang telah ditetapkan. Dosen terlihat lebih rileks dalam penyampaian materi dan jelas dalam pemberian tugas sesuai dengan saran dari peneliti. Keterampilan menyimak komprehensif dan kritis pada mahasiswa setelah diterapkan metode resitasi dapat dijelaskan sebagai berikut: (1) Tujuan menyimak komprehensif dan kritis yang diamati secara seksama meningkat menjadi 70,01\%, terjadi peningkatan yang signifikan dari praobservasi; (2) Tahap-tahap menyimak yang diamati secara seksama meningkat menjadi 77,02; (3) Penerimaan, perhatian, dan pemberian makna dari pesan yang disampaikan meningkat menjadi 75,05\%; dan (4) Proses penafsiran dalam mencari kesalahan atau kekeliruan bahkan mencari kebenaran atau kebaikan dari ujaran seseorang meningkat menjadi $78,56 \%$.

Konsep pembelajaran dengan menggunakan metode resitasi merupakan metode pembelajaran yang berisikan langkah-langkah yang efektif digunakan untuk meningkatkan keterampilan menyimak komprehensif dan kritis sehingga memperoleh hasil yang memuaskan pada siklus II. Hal tersebut terbukti selama 
proses kegiatan belajar yang memperoleh hasil yang baik pada siklus II. Terjadi peningkatan sebesar $18 \%$ dari siklus I ke siklus II.Pada siklus II dosen telah menerapkan metode resitasi dengan seksama, sehingga pembelajaran menyimak komprehensif dan kritis pada mahasiswa telah berkembang dengan baik.Hal tersebut didukung hasil kinerja mahasiswa. Peningkatan yang signifikan mencapai target KKM 75 dari 75\% mahasiswa. Penelitian dinyatakan selesai dan berhasil.

\section{SIMPULAN}

Berdasarkan hasil penelitian, maka dapat disimpulkan; (1) Proses menyimak komprehensif dan kritis dengan metode resitasi pada mahasiswa kelas A Sore semester 2 angkatan 2017 meningkat menjadi 78; dan(2) keterampilan menyimak komprehensif dan kritis dengan metode resitasi pada mahasiswa kelas A Sore semester 2 angkatan 2017 pada prasiklus 35\%, pada siklus I 60,01\%, dan siklus II meningkat menjadi $78,50 \%$.

\section{DAFTAR PUSTAKA}

Iskandar. 2012. Peneltian Tindakan Kelas. Jakarta: Referensi.

Murniasih, R. \& Fayeldi, T. 2017. Metode Resitasi untuk Meningkatkan Pemahaman Konsep pada Mata Kuliah Dasar-Dasar Pemrograman Komputer. JurnalEdukasi. V(1): 8-12.

Tarigan, H. G 1997. Keterampilan Menyimak, Modul 1-5. Departemen Pendidikan dan Kebudayaan.

Tarigan, H. G. 1994 Menyimak: Sebagai Suatu Keterampilan Berbahasa. Bandung: Aksara.

Slameto. 2010. Belajer dan Faktor-Faktor yang Memperngaruhi. Jakarta: Rineka

Sudirman, A. M. 1992. Interaksi dan Motivasi Belajar Mengajar. Jakarta: Raja Grafindo Persada.

Sudjana, N. 2005. Metode Penelitian Pendidikan Pendekatan KuantitatifKualitatif dan $R \& D$. Bandung: PT Remaja Rosdakarya.

Suwandi, S. 2011. Peneltian Tindakan Kelas (PTK) \& Penulisan Karya Ilmiah. Surakarta: Yuma Pressindo. 